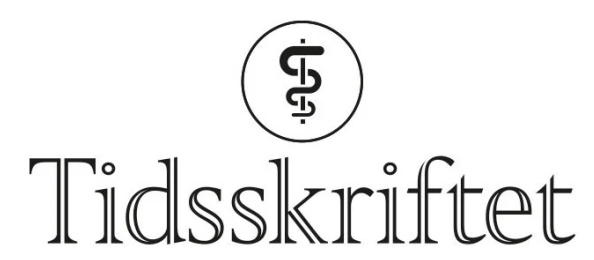

DEN NORSKE LEGEFORENING

\title{
Bioteknologiloven og legers holdninger
}

DEBATT

\section{INGUNN MARIE STADSKLEIV ENGEBRETSEN}

ingunn.engebretsen@uib.no

Ingunn Marie Stadskleiv Engebretsen er professor på Senter for internasjonal helse, Universitetet i Bergen. Hun har bakgrunn fra klinisk arbeid og forskning innen barne- og ungdomspsykiatri samt kvalitativ og epidemiologisk forskning.

Forfatteren har fylt ut ICMJE-skjemaet og oppgir ingen interessekonflikter.

\section{De nye vedtakene innenfor bioteknologiloven krever implementering av nytt lovverk i helsesystemet. Leger bør gripe anledningen til å reflektere over egne holdninger og kommunikasjon med pasientene og hverandre.}

Bioteknologiloven ble liberalisert i mai (1). Det har vært en langdryg og komplisert prosess, der teknologiske og medisinske muligheter, juss og etikk skulle veves sammen i politiske beslutninger. Resultatet er kjent: Det er nå vedtatt at assistert befruktning til enslige, eggdonasjon, tilbud om non-invasiv prenatal test (NIPT) og tidlig ultralyd er lov i Norge. Dette ble diskutert i Tidsskriftet tidligere i vår (ㅁ). Leger har imidlertid virket noe tilbakeholdne i nyhetsbildet om hvilke implikasjoner endring av lovverket får for gjeldende praksis. Dette står i kontrast til andre gruppers uttalelser og legers synlighet i den pågående covid-19-pandemien.

\section{Positive og negative konsekvenser}

I mediedekningen av den nye endringen av bioteknologiloven er det brukt kjente teknikker, inkludert det å la enkeltindivider stå fram og fortelle sin historie. På den ene side har vi sett hvordan enkeltindivider mener tidligere norsk lovverk har vært problematisk for dem og at en endring slår positivt ut. Det har vært alt fra behov for eggdonasjon etter for eksempel fjerning av eggstokkene til likestillingsprinsipper, sterkt barneønske som enslig, $\emptyset$ nske om tidlig fosterdiagnostikk eller hensyn til eget liv og egen helse.

«Sannsynligvis blir pasienter, kollegaer og våre arbeidsmiljø påvirket av hvordan vi kommuniserer om ulike tilstander og utfordringer» 
På den annen side har flere stått fram og uttrykt bekymring for hvilke negative ettervirkninger disse lovendringene kan få i samfunnet. Flere foreldre til barn med trisomi 21 har stått fram og uttrykt bekymring og vært frustrert over hvordan de har blitt møtt. For eksempel var det i TV 2-nyhetene 26.5.2020, den datoen man stemte over bioteknologiloven, enda en reportasje med et foreldrepar som viste fram sin blide toåring med Downs syndrom og fortalte at de hadde måttet «stå imot presset [til å ta abort]» (3). Videre signaliserte de at «legestanden» var synkron og ensrettet, med innbakte formaninger om å gjøre som «de fleste andre» - «å velge barnet bort». Oppropet \#PLASSTILALLE ble organisert mot det initiativtakerne kalte «unødvendig» fosterdiagnostikk, med markante samfunnsprofiler i spissen (4). I oppropet ytres bekymring for at $\varnothing \mathrm{kt}$ bruk av fosterdiagnostikk vil bidra til at flere velger abort der det blir påvist visse genetiske tilstander.

Det vi hører i mediene, er enkeltpersoners historier. Det er vanskelig å få den fulle oversikten over hvordan norske pasienter blir møtt ved ulike avdelinger i Norge. Kanskje de som har hatt mer nøytrale opplevelser i helsevesenet, ikke uttaler seg? At noen har slike negative opplevelser, er imidlertid alvorlig nok.

\section{Informasjon til pasientene}

Leger skal informere, og den nye loven gir intet unntak. Men, informasjonen gitt av leger kan oppleves vond for pasienter som føler sårbarhet og avmakt -ikke kun på grunn av innholdet i informasjonen, men fordi legene ikke klarer å være nøytrale eller fordomsfrie. I en hektisk hverdag kan legen være opptatt av å ha «sitt på det tørre», nemlig å kunne dokumentere at man har gitt informasjon om sykdom og risiko. Mottakeren kan føle seg misforstått, ignorert eller overveldet.

Sannsynligvis blir pasienter, kollegaer og våre arbeidsmiljø påvirket av hvordan vi kommuniserer om ulike tilstander og utfordringer. Dersom man snakker om barn med spesielle behov som «dyre for samfunnet», er ikke det et nøytralt utsagn. Dersom man som lege har lav toleransegrense for noen av de utfordringene visse arvelige tilstander kan føre med seg, vil nok enkle psykologiske mekanismer gjøre at de holdningene blir kommunisert. Og dersom man har et sterkt verdisyn mot abort, vil det sannsynligvis skinne igjennom.

\section{«Selvrefleksjonsjobben blir aldri ferdig»}

Når den nye bioteknologiloven skal iverksettes, har vi en gyllen mulighet til å reflektere rundt egne verdier, holdninger og adferd. Helsevesenet er nødt til å finne løsninger for systemimplementering av det nye lovverket. Hva vi formidler og hvordan vi formidler det, kan styre hvordan vi blir oppfattet. En pasientsentrert - og interessert kommunikasjonsstil, i tillegg til godt klinisk arbeid, kan komme pasientene til gode og være både «hjelpende, lindrende og trøstende» (5). Selvrefleksjonsjobben blir aldri ferdig.

\section{LITTERATUR}

1. LOV-2020-06-19-78. Lov om endringer i bioteknologiloven mv. https://www.regjeringen.no/no/dokumenter/prop.-34-l-20192020/id2682309/ Lest 31.8.2020.

2. Eggebøe TM, Kahrs BH. T.M. Eggeboe og B.H. Kahrs svarer. Tidsskr Nor Legeforen 2020; 140: 962. [PubMed]

3. Baraldsnes R, Fremstad M, Prestegård S. Amandas (2) foreldre:- Legen sa det ordner seg, de aller fleste «tar dem vekk». TV2 26.5.2020. https://www.tv2.no/a/11467941/ Lest 31.8.2020.

4. \#plasstilalle. https://plasstilalle.com/ Lest 31.8.2020. 
Publisert: 22. september 2020. Tidsskr Nor Legeforen. DOI: 10.4045/tidsskr.20.0487 Mottatt 29.5.2020, første revisjon innsendt 4.8.2020, godkjent 31.8.2020.

(C) Tidsskrift for Den norske legeforening 2023. Lastet ned fra tidsskriftet.no 26. april 2023. 